\title{
PERLINDUNGAN HUKUM TERHADAP PEREMPUAN KORBAN KEKERASAN DALAM RUMAH TANGGA
}

\author{
1Imam Sukadi dan ${ }^{2}$ Mila Rahayu Ningsih \\ 1,2Fakultas Syariah Universitas Islam Negeri Maulana Malik Ibrahim Malang \\ 1imam_sukadi@syariah.uin-malang.ac.id \\ 2milarahayu2105@gmail.com
}

\begin{abstract}
Domestic violence that makes women victims is a form of action that is against the principles of humanity. This causes violence against women in domestic violence to be one of the acts that violates human rights so that legal instruments are needed that are able to provide protection to women who are victims and are able to eradicate violence against women in Indonesia. The purpose of this study was to determine the legal protection measures provided to women as victims of domestic violence. The analysis of legal materials used in this research is prescriptive analysis, which is a type of normative legal research.
\end{abstract}

Keywords: Domestic Violence, Women, Legal Protection

\begin{abstract}
Abstrak
Kekerasan dalam rumah tangga yang menjadikan perempuan sebagai korban merupakan salah satu bentuk perbuatan yang bertentangan dengan sendi-sendi kemanusiaan. Hal ini menyebabkan perbuatan kekerasan terhadap perempuan dalam kekerasan dalam rumah tangga merupakan salah satu perbuatan yang melanggar HAM sehingga dibutuhkan instrumeninstrumen hukum yang mampu memberikan perlindungan kepada perempuan-perempuan yang menjadi korban serta mampu menghapus kekerasan terhadap perempuan di Indonesia. Tujuan penelitian ini adalah untuk mengetahui upaya perlindungan hukum yang diberikan kepada perempuan sebagai korban kekerasan dalam rumah tangga. Analisis bahan hukum yang digunakan dalam penelitian ini adalah preskriptip analisis yang merupakan penelitian dalam jenis penelitian hukum normatif.
\end{abstract}

Kata kunci: Kekerasan dalam rumah tangga, Perempuan, Perlindungan Hukum

\section{PENDAHULUAN}

Kekerasan terhadap perempuan dapat dikategorikan sebagai violence against women, gender based violence, gender violence dan sebagainya merupakan salah satu permasalahan kronis yang dihadapi jutaan perempuan di seluruh dunia. Maraknya permasalahan kekerasan terhadap perempuan 
ini segera direspon oleh Perserikatan Bangsa-Bangsa dalam kongres pada tahun 1994 tentang penghapusan tindak kekerasan terhadap perempuan. Dalam bagian konsideran deklarasi tersebut antara lain dikatakan bahwa tindak kekerasan terhadap perempuan adalah perwujudan ketimpangan historis dari hubungan kekuasaan antara kaum laki-laki dan perempuan yang telah mengakibatkan dominasi dan diskriminasi terhadap kaum perempuan oleh kaum laki-laki dan hambatan bagi kemajuan terhadap mereka. Selanjutnya dikatakan pula bahwa tindakan kekerasan terhadap perempuan merupakan salah satu mekanisme sosial penting yang menempatkan kaum perempuan dalam posisi sub ordinasi di hadapan kaum laki-laki (Setiadi, 2001). onstruksi pola pikir yang seolah menempatkan posisi laki-laki yang lebih superior dibandingkan perempuan menjadi sebuah hal yang mampu menjadi pemicu terjadinya kekerasan maupun bentuk kejahatan lain yang dilakukan terhadap perempuan.

Kekerasan terhadap perempuan menjadi salah satu permasalahan dari sekian banyak permasalahan-permasalahan pokok mengenai HAM yang terus coba untuk dihadapi negara-negara di dunia, termasuk Indonesia. Dari sekian banyak bentuk kekerasan terhadap perempuan, salah satu hal yang paling banyak disoroti adalah perbuatan kekerasan terhadap perempuan dalam rumah tangga. Kekerasan dalam rumah tangga yang terjadi terhadap perempuan merupakan salah satu bentuk perbuatan yang bertentangan dengan konsep dasar kemanusiaan yang ada.

Ditinjau dari tataran instrumen hukum, Undang-Undang Dasar Negara Republik Indonesia Tahun 1945 sebagai konstitusi negara pada dasarnya telah mengatur secara jelas pemberian hak kesetaraan dan perlindungan bagi perempuan dalam ikatan perkawinan yang tercantum dalam Pasal 28G ayat (1) yang berbunyi "Setiap orang berhak atas perlindungan diri pribadi, keluarga, kehormatan, martabat, dan harta benda yang di bawah kekuasaannya, serta berhak atas rasa aman dan perlindungan dari ancaman ketakutan untuk berbuat atau tidak berbuat sesuatu yang merupakan hak asasi". Upaya serius dalam penghapusan tindak kekerasan terhadap perempuan juga telah coba direspon pemerintah dengan disahkannya Undang-Undang Nomor 23 Tahun 2004 Tentang Penghapusan Kekerasan Dalam Rumah Tangga (UU PKDRT). Meski demikian, pengesahan instrumen hukum ini dirasa tidak cukup bila melihat fakta yang terjadi di masyarakat yang menunjukkan tingginya frekuensi tindak kekerasan dalam rumah tangga yang menempatkan perempuan sebagai korban didalamnya.

Merebaknya kejahatan yang terjadi terhadap perempuan sudah sampai pada tahap yang sangat menghawatirkan. Fakta bahwa data pelaporan tindak kekerasan terhadap perempuan yang berbanding terbalik dengan jumlah pemberian perlindungan dan penegakkan hukum terhadap kasus-kasus 
kekerasan yang menjadikan kaum perempuan sebagai korban telah mencapai titik yang sangat menghawatirkan. Pada tahun 2019, Badan Pusat Statistik merekam terdapat 5.444 pengaduan terkait kasus kekerasan terhadap perempuan yang terjadi di seluruh Indonesia dan hanya ada 1.177 kasus yang ditegakkan hukum terhadapnya. Data ini pun tidak termasuk kasus yang tidak dilaporkan kepada pihak yang berwenang (dark number).

Komisi Nasional (Komnas) Perempuan memaparkan catatan tahunan tentang kekerasan terhadap perempuan menunjukkan peningkatan jumlah kasus secara konsisten dan signifikan. Catatan tahunan (Catahu) Komnas Perempuan pada tahun 2020 mencatat jumlah kasus Kekerasan terhadap Perempuan (KtP) sepanjang tahun 2020 mencapai angka 299.911 kasus, dengan kasus yang paling menonjol berada di Ranah Personal. Kasus kekerasan dalam rumah tangga terhadap perempuan mencapai persentase sebanyak 50\% dengan 3.221 kasus.

Meski pun angka kekerasan terhadap perempuan dalam rumah tangga telah mencapai situasi yang amat serius, nampak bahwa pemberian perlindungan hukum serta penegakan hukum terhadap kasus-kasus yang terjadi masih mengalami hambatan yang berat. Salah satu alasan mengapa kekerasan terhadap perempuan dalam rumah tangga menghadapi rintangan dalam proses perlindungan terhadap korban serta penegakan hukum terhadap kasus yang terjadi adalah kasus kekerasan ini terjadi dalam lingkup rumah tangga dan berlangsung dalam hubungan personal yang intim, yaitu antara suami dan isteri dilandasi oleh hubungan dalam lembaga perkawinan yang di atur pula oleh Kitab Undang-undang Hukum Perdata atau Undang-Undang Nomor 1 Tahun 1974 tentang Perkawinan (Abdurrachman, 2010). Kedudukan pelaku dan korban yang sedemikian ini menyebabkan kekerasan terhadap perempuan dalam rumah tangga masih dipandang sebagai bagian dari hukum privat sehingga penyelesaian kasus ini lebih sering diarahkan untuk damai atau diselesaikan secara internal keluarga. Penyelesaian kasus kekerasan terhadap perempuan yang terus menerus hanya diarahkan untuk diselesaikan di ranah privat atau bahkan berujung damai inilah yang seringkali menimbulkan kerugian kepada korban karena ketiadaan pemberian sanksi yang mampu memberi efek jera kepada pelaku kekerasan.

Kekerasan dalam rumah tangga baik berupa kekerasan fisik, psikis, seksual maupun penelantaran yang menempatkan perempuan sebagai korban dapat menimbulkan korban baik memerlukan upaya perlindungan terhadap korban, termasuk pemulihan kesehatan secara fisik dan psikis (Laurika, 2016). Bagi pelaku kekerasan dalam rumah tangga diperlukan upaya penegakan hukum dalam menyelesaikan perkara kekerasan ini melalui proses peradilan. Kendala-kendala dalam penyelesaian perkara 
KDRT perlu diatasi melalui peran pemerintah dan pemerintah daerah bekerjasama dengan masyarakat agar pelaksanaan penghapusan kekerasan dalam rumah tangga dapat direalisasikan.

Melihat fakta lemahnya kedudukan perempuan dalam hal ini, Indonesia sebagai negara yang berdiri dan menjalankan fungsinya berlandaskan pada hukum wajib bergerak cepat merespon kebutuhan genting mengenai perlindungan hukum terhadap perempuan korban kekerasan dalam rumah tangga baik. Peneliti dalam penelitian ini mencoba untuk menganalisis perlindungan hukum terhadap perempuan korban kekerasan dalam rumah tangga. Tujuan dari penelitian ini adalah untuk memberikan pemaparan mengenai perlindungan secara menyeluruh bagi kaum perempuan korban kekerasan baik berupa perlindungan dengan menegakkan hukum terhadap pelaku maupun dengan upaya pemulihan kesehatan fisik dan psikis bagi kaum perempuan yang menjadi korban kekerasan dalam rumah tangga. Dengan adanya analisis terkait hal ini, diharapkan adanya penegakan hukum yang adil bagi kaum perempuan yang menjadi korban dan masyarakat mampu memahami isu terkait serta dapat ikut berpartisipasi dalam memberikan dukungan secara moril bagi korban terdampak.

\section{KAJIAN PUSTAKA}

\section{Teori Perlindungan Hukum}

Pasal 1 ayat 3 Undang-Undang Dasar Tahun 1945 menyatakan bahwa "Indonesia adalah negara hukum". Ayat ini memuat kandungan bahwa negara menjamin hak-hak hukum warga negaranya dengan memberikan perlindungan hukum dan perlindungan hukum akan menjadi hak bagi setiap warga negara. Satjipto Rahardjo memaparkan bahwa perlindungan hukum adalah upaya melindungi kepentingan seseorang dengan cara mengalokasikan suatu kekuasaan kepadanya untuk bertindak dalam rangka kepentingannya tersebut (Satjipto Raharjo, 2005). Perlindungan hukum menurut Satjipto Raharjo adalah memberikan pengayoman kepada hak asasi manusia yang dirugikan orang lain dan perlindungan tersebut diberikan kepada masyarakat agar mereka dapat menikmati semua hak-hak yang diberikan oleh hukum atau dengan kata lain perlindungan hukum adalah berbagai upaya hukum yang harus diberikan oleh aparat penegak hukum untuk memberikan rasa aman, baik secara pikiran maupun fisik dari gangguan dan berbagai ancaman dari pihak manapun.

Perlindungan hukum adalah penyempitan arti dari perlindungan, dalam hal ini hanya perlindungan oleh hukum saja (CST Kancil, 1980). Perlindungan yang diberikan oleh hukum, terkait pula dengan adanya hak dan kewajiban, dalam hal ini yang dimiliki oleh manusia sebagai subyek 
hukum dalam interaksinya dengan sesama manusia serta lingkungannya. Sebagai subyek hukum manusia memiliki hak dan kewajiban untuk melakukan suatu tindakan hukum.

Philipus M. Hadjon menyatakan bahwa sarana perlindungan hukum ada dua, yaitu: sarana perlindungan hukum preventif dan sarana perlindungan hukum represif (Santoso \& Arifin, 2017). Philipus M. Hadjon juga merumuskan prinsip perlindungan hukum bagi rakyat Indonesia dengan metode menggabungkan muatan ideologi Pancasila dengan konsepsi perlindungan hukum dalam hukum barat. Konsep perlindungan hukum bagi rakyat dalam hukum barat bersumber pada konsep pengakuan, perlindungan terhadap hak-hak asasi manusia, konsep-konsep rechtsstaat, dan the rule of law. Ia menerapkan konsepsi hukum barat sebagai kerangka berpikir dengan Pancasila sebagai Ideologi dan dasar falsafah negara. Sehingga prinsip perlindungan hukum bagi rakyat Indonesia adalah prinsip pengakuan dan perlindungan terhadap harkat dan martabat manusia yang bersumber pada Pancasila dan prinsip Negara hukum yang berdasarkan Pancasila.

\section{Perlindungan Terhadap Perempuan}

Hukum pidana Indonesia masih menjadi pion utama dalam memberikan perlindungan hukum dan penegakan hukum bagi setiap pelaku kekerasan dalam rumah tangga. Beberapa ancaman pidana bagi pelaku kekerasan dalam KUHP yang sebelum berlakunya dalam UU PKDRT sebagai instrumen hukum positif di Indonesia yang menjadi acuan aparat penegak hukum untuk menegakkan hukum yang memberikan perlindungan bagi kaum perempuan yang menjadi korban kekerasan dalam rumah tangga (Prihastuti, 2016). Selain itu, tersusunnya Rencana Aksi Nasional Penghapusan Kekerasan Terhadap Perempuan (RAN-PKTP), pembangunan fasilitas-fasilitas seperti ruang pelayanan khusus (RPK) untuk anak dan perempuan di kantor Polda dan Polres dan Pusat Pelayanan Terpadu Perlindungan Perempuan dan Anak (P2T-P2A) di daerah menunjukkan adanya upaya serius dari pemerintah dalam menghapuskan kasus kekerasan terhadap perempuan (Andang Sari \& Haryani Putri, 2020). Pembentukan konstruksi hukum serta fasilitas penunjang lainnya diharapkan mampu mengurangi atau bahkan menghapuskan kasus-kasus kekerasan yang menempatkan perempuan sebagai korban.

Dari aspek yuridis, eksistensi UU PKDRT merupakan salah satu upaya pembaharuan hukum yang berpihak pada kelompok yang dianggap rentan terhadap tindak kekerasan khususnya perempuan (Andang Sari \& Haryani Putri, 2020). Pada UU PKDRT terdapat beberapa perbuatan kekerasan yang merupakan bagian dari kekerasan terhadap perempuan, seperti rumusan Pasal 5 Undang-Undang Penghapusan Kekerasan Dalam Rumah Tangga 
tentang pengertian kekerasan dalam rumah tangga yang meliputi, kekerasan fisik, psikis, seksual, dan penalantaran keluarga. Beberapa pasal tersebut sudah sangat jelas arah yang ingin dicapai oleh UU PKDRT. Salah satu tujuan yang ingin dicapai adalah memberikan perlindungan hukum bagi perempuan korban kekerasan dalam rumah tangga (Prihastuti, 2016). Undang-undang ini secara jelas telah mengatur secara jelas dan tegas bahwa segala bentuk tindakan kekerasan dalam rumah tangga merupakan kejahatan terhadap martabat manusia serta perlunya pemberian perlindungan dari aparat dan masyarakat pada kaum perempuan yang menjadi korban kekerasan dalam rumah tangga.

Pada umumnya, pelaku KDRT adalah suami dan korbannya adalah istri dan/atau anak-anaknya, akan tetapi kekerasan terhadap perempuan (istri) tidak mendapatkan perhatian yang memadai dalam sistem hukum termasuk aparat hukum dan budaya hukum yang ada di masyarakat Indonesia karena pemaknaan kekerasaan atau persepsi mengenai tindak kekerasan yang ada di dalam masyarakat (Harkristuti Harkrisnowo, 2000). Kekerasan terhadap perempuan adalah setiap tindakan kekerasan berbasis gender yang mengakibatkan kerugian fisik, seksual atau psikologis atau penderitaan terhadap perempuan, termasuk tindakan yang berupa ancaman, pemaksaan atau perampasan kebebasan, apakah itu terjadi di publik ataupun dalam kehidupan pribadi. Hal ini sangat berpengaruh terhadap timbulnya suatu tindakan yang sudah tidak asing lagi kita dengar yaitu tindak Kekerasan Dalam Rumah Tangga yang mempunyai pengertian tersendiri bagi suatu negara tertentu.

Mencegah kekerasan terhadap perempuan berarti berbicara tentang salah satu aspek dari upaya-upaya penegakkan HAM perempuan pada umumnya. HAM perempuan yaitu sesuatu yang spesifik sehingga perlu dibakukan untuk mencegah sejumlah besar pelanggaran yang terjadi bagi perempuan. Hak perempuan, khususnya didalam rumah juga memiliki implikasi terhadap kehidupan kebebasan dan keadilan yang sama haknya dengan laki-laki (Titahelu, 2016).

\section{METODE}

Kajian penulisan ini menggunakan studi literature hukum. Menurut Burhan Bungin "Metode litaratur adalah salah satu metode pengumpulan data historis" (Bungin, 2008). Ini berarti bahwa studi literatur merupakan jenis studi yang menekankan pengumpulan bahan hukum melalui pengkajian 
buku-buku yang berkaitan dengan topik penelitian terkait. Adapun metode analisis bahan hukum yang digunakan adalah metode preskriptis analitis.

\section{HASIL DAN PEMBAHASAN}

\section{A. Konsep Kekerasan dalam Rumah Tangga}

Konsep kekerasan dalam rumah tangga (family violence) sebagaimana disebut dalam pasal UU PKDRT diadopsi dari konsep domestic violence yang pada dasarnya adalah penyalahgunaan kekuasaan seseorang untuk mengontrol pihak lain yang tersubordinasi, yaitu pihak-pihak yang berada dalam posisi atau kedudukan yang tidak setara atau berada dibawah kekuasaan pihak lain sehingga menimbulkan rasa takut, hilang rasa percaya diri serta hilang kemampuan untuk bertindak dan sebagainya (Hartono, 2014). Dalam hal ini, kaum perempuan dominan menjadi pihak yang dikategorikan sebagai pihak yang berada dalam posisi yang powerless dan inferior sehingga rentan terhadap kekerasan dalam rumah tangga.

Pada hakikatnya kejahatan dengan kekerasan (violent crimes) tidak hanya terbatas pada bentuk kejahatan yang melibatkan kekerasan jasmani semata. Bila ditelaah lebih dalam, terminologi kekerasan dapat pula diterjemahkan sebagai bentuk tindakan yang menimbulkan penderitaan fisik maupun psikologis pada korban. Pemaknaan mengenai kekerasan fisik maupun psikologis ini telah tertuang dalam Pasal 1 angka 1 Undang-Undang Penghapusan Kekerasan Dalam Rumah Tangga (UU PKDRT) yang menyebutkan bahwa "Kekerasan dalam rumah tangga adalah setiap perbuatan terhadap seseorang terutama perempuan, yang berakibat timbulnya kesengsaraan atau penderitaan secara fisik, seksual, psikologis dan atau penelantaran rumah tangga termasuk ancaman untuk melakukan perbuatan, pemaksaan atau perampasan kemerdekaan secara melawan hukum dalam lingkup rumah tangga." (Hartono, 2014). Perserikatan BangsaBangsa (PBB) dalam Vienna Declaration and Programme of Action juga mendefiniskan bahwa kekerasan terhadap perempuan merupakan segala tindakan kekerasan tindakan kekerasan berdasarkan gender yang mengakibatkan kerugian atau bahaya atau pun melukai baik secara fisik, seksual, psikologi maupun penderitaan kepada kaum perempuan, termasuk pula tindakan-tindakan mengancam, kekerasan, perampasan secara sewenang-wenang terhadap kebebasan di ranah publik maupun kehidupan pribadi (Delmiati, 2016). Ini menunjukkan bahwa permasalah kekerasan dalam rumah tangga merupakan sebuah hal yang kompleks dan tidak dapat serta merta diselesaikan hanya melalui mediasi antar kedua belah pihak, tetapi dibutuhkan penanganan khusus yang berkelanjutan dalam menghadapinya. 
Sesuai dengan "spirit of law" UU PKDRT serta instrumen hukum terkait lainnya, perempuan yang menjadi korban kekerasan dalam rumah tangga berhak dan harus mendapat perlindungan dari negara serta seluruh komponen dalam struktur masyarakat agar terhindar dan terbebas dari kekerasan atau ancaman kekerasan, penyiksaan, atau perlakuan yang merendahkan derajat dan martabat kemanusiaan (Titahelu, 2016). Namun, kenyataan yang terjadi sungguh berbanding terbalik dengan cita-cita perlindungan serta penegakan hukum yang coba diraih melalui UU PKDRT. Dalam penyelesaian perkara pidana kekerasan dalam rumah tangga, seringkali hukum terlalu mengedepankan hak-hak tersangka atau terdakwa, dan mengesampingkan hak-hak korban. Banyak ditemukan perempuanperempuan yang menjadi korban kekerasan dalam rumah tangga yang tidak memperoleh perlindungan hukum yang memadai, baik perlindungan yang sifatnya immateriil maupun materiil.

Perempuan sebagai korban dalam kasus ini di dalam proses pengadilan diposisikan sebagai alat bukti yang memberi keterangan dan tidak memiliki keleluasaan dalam memperjuangkan hak-haknya sebagai seorang manusia yang memiliki derajat dan martabak serta sebagai seorang warga negara yang berhak diberikan perlindungan oleh hukum yang berlaku. Dalam hal ini, korban juga tidak diberikan kewenangan dan tidak terlibat secara aktif dalam proses penyidikan dan persidangan sehingga kehilangan kesempatan untuk memperjuangkan hak-hak dan memulihkan keadaannya akibat tindak kekerasan (Yulia, 2009). Hal ini tentu tidak sejalan dengan cita-cita instrumen-instrumen hukum yang telah dibangun karena tidak berhasil melindungi kedudukan perempuan sebagai manusia bermartabat yang memiliki hak sekaligus sebagai korban tindak kekerasan dalam rumah tangga.

\section{B. Perlindungan Hukum Bagi Perempuan Korban Kekerasan Dalam Rumah Tangga}

Dalam tataran hukum intenasional, Declaration of Human Right menjadi perangkat internasional menjadi instrumen hukum induk yang melahirkan beberapa instrument lainnya yang bergerak dalam ranah pemberian dan perlindungan hak-hak bagi perempuan di seluruh dunia seperti Convention On The Political Rights of Women (UN 1952) yang diratifikasi oleh Indonesia dengan UU No. 68 Tahun 1958 Tentang: Persetujuan Konvensi Hak-Hak Politik Kaum Wanita, Convention on The Elimination of Discrimination of All Forms of Discrimination Against Women (UN 1979) yang diimplementasikan oleh Indonesia melalui UU No. 7 Tahun 1984, dan Declaration On The Elemination Of Violence Against Women (UN 1973) (Sapardjaja, Komariah Emong, Sutriya, 2008). Pembentukan 
perangkat-perangkat hukum dalam skala global ini menunjukkan adanya upaya secara masif dan komprehensif dalam penghapusan kekerasan terhadap perempuan.

Sementara itu bila menilik lebih dalam lagi mengenai perangkat hukum perlindungan hak perempuan secara nasional, jauh sebelum lahirnya Declaration of Human Right, konvensi, konvenan serta perangkat hukum international lainnya, Indonesia telah berikrar dalam pembentukan UUD NRI 1945 yaitu dalam Preambule yang berbunyi "Bahwa sesungguhnya kemerdekaan itu ialah hak segala bangsa dan oleh sebab itu maka penjajahan diatas dunia harus dihapuskan, karena tidak sesuai dengan perikemanusiaan dan perikeadilan" (Sapardjaja, Komariah Emong, Sutriya, 2008). Disahkannya Undang-Undang Nomor 23 Tahun 2004 Tentang Penghapusan Kekerasan Dalam Rumah Tangga (UU PKDRT) pada 22 September Tahun 2004 semakin memperkokoh konstruksi hukum dalam memberantas kekerasan di Indonesia (Rahmawaty, 2014). Dengan berlakunya UU PKDRT serta perangkat hukum nasional lainnya diharapkan mampu menjadi langkah awal dan landasan dalam penegakan hukum yang adil dalam penyelesaiannya kasus-kasus kekerasan terhadap perempuan. Pengesahan dan pemberlakuan UU PKDRT merupakan salah satu perwujudan negara dalam memberikan hak-hak kemanusiaan bagi seluruh warga negara. UU PKDRT terlahir untuk menyelamatkan para korban yang dominan berasal dari kaum perempuan dalam tindak kejahatan kekerasan dalam rumah tangga. Hal ini merupakan pertanda baik bagi para perempuan korban kekerasan dalam rumah tangga karena dapat melakukan penuntutan dan dilindungi secara hukum.

Secara umum dalam UU PKDRT, ada beberapa unsur penting yang perlu dipahami yakni pertama, penghapusan kekerasan dalam rumah tangga dilaksanakan berdasarkan asas penghormatan hak asasi manusia, keadilan dan kesetaraan gender, non diskriminasi dan perlindungan korban serta untuk membangun dan menjaga keharmonisan rumah tangga (Rahmawaty, 2014). Kedua, UU PKDRT menetapkan bentuk-bentuk kekerasan dalam lingkup rumah tangga yaitu kekerasan fisik, kekerasan psikis, kekerasan seksual, yang penjatuhan hukumannya pada umumnya menggunakan pasal 351 hingga 355 KUHP meskipun dalam pasal-pasal tersebut tidak secara spesifik menyebutkan kekerasan dalam rumah tangga (Delmiati, 2016). Ketiga, penelantaran rumah tangga yang mempunyai arti bahwa setiap orang dilarang untuk menelantarkan orang dalam lingkup rumah tangganya, padahal menurut hukum yang berlaku baginya atau karena persetujuan atau perjanjian ia wajib memberikan kehidupan, perawatan, atau pemeliharaan kepada orang tersebut (Santoso \& Arifin, 2017). Keempat, aparat penegak hukum yang menjadi representasi pemerintah serta seluruh komponen masyarakat memiliki kewajiban dalam upaya pencegahan serta 
penyelesaiannya kasus kekerasan dalam rumah tangga. Seluruh unsur yang telah disebutkan diatas merupakan apek yang menyokong satu sama lain. Penanganan kasus-kasus kekerasan dalam rumah tangga yang menempatkan kaum perempuan sebagai korban hendaknya memerhatikan, memahami dan menerapkan empat unsur diatas agar terbentuknya susunan proses penanganan kasus kekerasan dalam rumah tangga yang komplet.

Meski demikian, dikeluarkannya berbagai regulasi berperspektif gender untuk melindungi perempuan belum mampu sepenuhnya menjamin perempuan dari terbebas dari tindakan pelanggaran HAM yang salah satunya adalah tindak kekerasan dalam rumah tangga. Ancaman kekerasan yang terjadi di dalam rumah tangga yang sering dilakukan oleh anggota keluarganya sendiri sulit dapat dilihat oleh orang luar. Banyak terjadi kasus kekerasan dalam rumah tangga dimana perempuan yang menjadi korban sering tidak berani untuk melapor ke pihak berwenang dikarenakan alasanalasan tertentu seperti adanya ikatan kekeluargaan, nilai-nilai sosial tertentu, nama baik (prestise) keluarga maupun dirinya atau korban merasa khawatir pelaku melakukan balas dendam terhadapnya (Prihastuti, 2016). Alasanalasan seperti inilah yang akhirnya menghambat atau bahkan menghentikan korban untuk melaporkan kasus yang dialaminya.

Sementara itu, pada ranah penegakan hukum ditemukan beberapa kendala dalam proses penegakan hukum dalam kasus kekerasan dalam rumah tangga. Pertama, adanya bias persepsi penegak hukum sejak tahap awal terhadap kekerasan dalam rumah tangga yang seringkali menganggap kekerasan dalam rumah tangga hanya sebagai persoalan privat saja dan kurang mendapat prioritas. Kedua, penegak hukum cenderung melihat KDRT adalah kekerasan fisik sehingga pembuktian terhadap dampak kekerasan hanya dilihat kasat mata saja padahal KDRT selalu menimbulkan dampak ganda (Abdurrachman, 2010). Ketiga, para penegak hukum sering tidak berpihak kepada korban perempuan, bukan karena ketidakpahaman dan ketiadaan perspektif perempuan dikalangan penegak hukum, tetapi juga struktur dan prosedur yang ketat menghalangi para penegak hukum untuk membuat terobosan dan interpretasi baru meskipun demi persoalan kemanusiaan (Delmiati, 2016). Beberapa kendala inilah yang pada akhirnya secara tidak langsung membentuk lingkungan penegakan hukum yang tidak ramah bagi perempuan yang menjadi korban kekerasan dalam rumah tangga.

Oleh sebab itu, untuk mewujudkan konstruksi hukum yang matang dalam upaya pemberantasan dan peniadaan kekerasan dalam rumah tangga, perlindungan hukum bagi perempuan korban kekerasan dalam rumah tangga serta penindakan para pelaku merupakan sebuah hal yang mutlak. Selanjutnya, perlunya adanya sistem yang diwujudkan oleh negara dibantu masyarakat dalam menciptakan perlindungan terhadap hak-hak perempuan 
korban kekerasan dalam rumah tangga (Santoso \& Arifin, 2017). Korban berhak mendapatkan perlindungan, pelayanan darurat serta pelayanan lainnya, penanganan secara rahasia serta pendampingan hukum dalam penyelesaian kasus yang dialaminya dari lembaga pemerintah maupun dari non govermental organization. Disamping itu, masyarakat, pemerintah maupun non govermental organization dituntut untuk memberikan bimbingan secara ruhani kepada korban dalam guna memperlancar proses healing korban dari aspek fisik maupun mental.

Semua penjelasan yang telah dipaparkan di atas bisa teralisasi dengan baik apabila ada itikad baik dari aparat penegak hukum, maupun dari masyarakat secara umum untuk menghormati dan menghargai hak-hak asasi perempuan yang melekat pada dirinya, karena pada dasarnya lengkap atau sempurnanya suatu undang-undang akan tetapi tidak dibarengi dengan itikad baik dari para pihak yang terlibat entah aparat penegak hukum atau pun kaum laki-laki yang kerap menjadi pelaku (Titahelu, 2016). Perlindungan hukum bagi perempuan bisa berjalan dengan baik bila hak-hak asasi perempuan bisa dijunjung tinggi serta terbentuknya struktur hukum serta penegakan hukum yang secara komprehensif mampu melindunginya kaum perempuan yang menjadi korban kekerasan khususnya dalam ranah rumah tangga.

\section{KESIMPULAN}

Perlindungan hukum kepada perempuan korban kekerasan dalam rumah tangga tidak cukup bila hanya berlandaskan pada pengesahan ratifikasi konvensi internasional atau instrumen-instrumen hukum lainnya. Pemberian perlindungan hukum kepada korban bisa diwujudkan bila telah terciptanya konsep tatanan konstruksi hukum di Indonesia dari hulu ke hilir yang matang, sistematis dan saling menyokong dalam arah yang sama dalam pemberian perlindungan hak-hak perempuan sebagai korban serta penegakan hukum yang diberikan kepada para pelaku kekerasan.

Dalam pembahasan lebih lanjut, diperlukan pula adanya pengkajian yang lebih mendalam terhadap budaya penegakan hukum terhadap isu ini beserta konsep yang lebih futuristis dalam perbaikan struktur dan prosedur yang dalam ranah penyelesaian di ranah sehingga para penegak hukum memiliki kesempatan dan ruang dalam membuat terobosan dan interpretasi baru dalam penyelesaian kasus kekerasan dalam rumah tangga.

\section{DAFTAR PUSTAKA}

Abdurrachman, H. (2010). Perlindungan Hukum Terhadap Korban Kekerasan Dalam Rumah Tangga Dalam Putusan Pengadilan Negeri Sebagai 
Implementasi Hak-Hak Korban. Jurnal Hukum Ius Quia Iustum, 17(3), 475-491. https://doi.org/10.20885/iustum.vol17.iss3.art7.

Andang Sari, \& Haryani Putri, A. (2020). Perlindungan Hukum Terhadap Perempuan Korban Kekerasan Dalam Rumah Tangga. Krtha Bhayangkara, 14(2), 236-245. https://doi.org/10.31599/krtha.v14i2.291.

CST Kancil. (1980). Pengantar Ilmu Hukum dan Tata Hukum Indonesia. Jakarta: Balai Pustaka.

Delmiati, S. (2016). Kebijakan Penegakan Hukum Terhadap Perempuan Korban Kekerasan dalam Rumah Tangga. 17(1), 3221-3255.

Harkristuti Harkrisnowo. (2000). Hukum Pidana dan Kekerasan terhadap Perempuan. Jakarta: KKCWPKWJ UI.

Hartono, B. (2014). Bentuk perlindungan hukum terhadap perempuan pelapor selaku saksi korban kekerasan dalam rumah tangga. Keadilan Progresif, 5(26), 1-19. Retrieved from http://jurnal.ubl.ac.id/index.php/KP/article/view/436.

Laurika, A. L. (2016). Perlindungan Hukum Terhadap Korban Tindak Pidana Kekerasan dalam Rumah Tangga. Lex Crimen, V(2), 30-36.

Prihastuti, A. (2016). Perlindungan Hukum Terhadap Perempuan Korban Kekerasan Dalam Rumah Tangga (Studi Kasus SPEK-HAM Solo). Publikasi Ilmiah, 17(1), 1-12.

Rahmawaty, A. (2014). Perlindungan hukum atas kekerasan terhadap perempuan: Kritisisme atas UU No. 23 Tahun 2004 Tentang PKDRT. Palastren, 7(1), 79-102.

Santoso, L., \& Arifin, B. (2017). Perlindungan Perempuan Korban Kekerasan Perspektif Hukum Islam. Journal de Jure, 8(2), 113. https://doi.org/10.18860/j-fsh.v8i2.3732.

Sapardjaja, Komariah Emong, Sutriya, M. (2008). KOMPENDIUM TENTANG HAK-HAK PEREMPUAN. Jakarta: Badan Pembinaan Hukum Nasional, Departemen Hukum dan Hak Asasi Manusia RI.

Satjipto Raharjo. (2005). Ilmu Hukum. In Ilmu Hukum. Bandung: Citra Aditya Bhakti.

Setiadi, E. (2001). Perlindungan Hukum Bagi Wanita Dari Tindakan Kekerasan. Mimbar No. 3 Th. XVII Juli-September 2001, (2), 338-354. 
Titahelu, M. G. S. dan J. A. S. (2016). Perlindungan Hukum Terhadap Hak Perempuan Sebagai Korban Kekerasan Dalam Rumah Tangga (Kajian Perspektif Hak Asasi Manusia).

Yulia, R. (2009). Restorative Justice Korban Kekerasan Dalam Rumah Tangga. Jurnal Hukum Dan Pembangunan. 